\title{
The effects of caffeine administered at different temperatures on foetal development
}

\author{
Marek Tomaszewski', Franciszek Burdan', Grażyna Olchowik², Monika Tomaszewska ${ }^{3}$ \\ ${ }^{1}$ Department of Human Anatomy, Medical University, Lublin, Poland \\ ${ }^{2}$ Department of Biophysics, Medical University, Lublin, Poland \\ 3 I Department of Radiology, Medical University, Lublin, Poland
}

Tomaszewski M, Burdan F, Olchowik G, Tomaszewska M. The effects of caffeine administered at different temperatures on foetal development. Ann Agric Environ Med. 2016; 23(1): 148-152. doi: 10.5604/12321966.1196871

\begin{abstract}
An easy access to products containing caffeine makes it widely consumed to excess by the general population, including pregnant women. Beverages containing caffeine are consumed at different temperatures (iced, hot, room temperature). Caffeine easily passes through biological membranes, including the blood-brain barrier, the placental barrier, and can also enter the amniotic fluid, breast milk and semen. The aim of this study was to evaluate the relationship between caffeine's developmental toxicity, and the solution's temperature (both low and high) administered to pregnant female rats. Fertilized females were randomly divided into two main groups: an experimental $(E)$ and a control group (C). The experimental groups received caffeine (30mg/day) in $10\left(E_{1}\right), 25\left(E_{2}\right)$ and $45^{\circ} \mathrm{C}\left(E_{3}\right)$. The females in the control group were given water at the same temperature $\left(C_{1}, C_{2}\right.$ and $\left.C_{3}\right)$. On the day 21 of pregnancy, the pregnant females were killed by decapitation, using a specially prepared laboratory guillotine, after which the mothers' internal organs were weighed. Additionally, the offspring were examined using standard teratological methods. The study found that caffeine administered to pregnant females at a dose of $30 \mathrm{mg} /$ day and at the temperatures of $10^{\circ} \mathrm{C}, 25^{\circ} \mathrm{C}$ or $45^{\circ} \mathrm{C}$ did not produce any teratogenic effects. The only sign of its adverse effect was the appearance of developmental abnormalities in the form of haematomas and saturated bleeding in the internal organs. These changes most frequently occurred in foetuses of females which received caffeine at $10^{\circ} \mathrm{C}$ or $45^{\circ} \mathrm{C}$.
\end{abstract}

Key words

caffeine, pregnancy, developmental anomalies

\section{INTRODUCTION}

Caffeine is a methylxanthine occurring naturally in more than 50 species of plant. In its processed form it is present in many foods and pharmaceutical products. An easy access to products containing this compound makes it widely consumed to excess by the general population, including pregnant women. Beverages containing caffeine are consumed at different temperatures, some are served chilled $\left(\mathrm{Cola}^{\oplus}, \mathrm{RedBull}^{\oplus}\right)$, others at room temperature (chocolate) or hot (coffee, tea).

Caffeine is quickly and completely absorbed from the gastrointestinal tract, and in just 30-45 minutes after ingestion is present in blood plasma. It easily passes through biological membranes, including the blood-brain barrier, the placental barrier, and can also enter the amniotic fluid, breast milk and semen [1].

On the basis of a number of experimental studies it has been proved that caffeine consumption during pregnancy carries a number of side-effects for both the mother and the developing foetus $[2,3,4,5,6,7,8,9]$. However, in the available literature, no studies have been found relating to the effects of caffeine administered at both low and high temperatures on foetal development.

The aim of this study was to evaluate the relationship between caffeine's developmental toxicity, and the solution's temperature administered to pregnant female rats.

Address for correspondence: Marek Tomaszewski: Department of Human Anatomy Medical University, Jaczewskiego 4, 20-090 Lublin, Poland

E-mail: tomaszewski.marek@gmail.com

Received: 20 August 2013; accepted: 02 October 2013

\section{MATERIALS AND METHOD}

The research was based on an animal experimental model, according to international guidelines for the assessment of developmental toxicity $[10,11]$, with the consent of the Ethics Committee at the Medical University of Lublin. The experimental part was carried out in the Centralna Zwierzętarnia AM (the Medical University's Central Animal House) in Lublin, under constant veterinary supervision.

The research was conducted on 48 white Wistar rats CRL:(WI)WUBR, provided by the Ośrodek Hodowli Zwierząt Laboratoryjnych (Centre for Breeding Laboratory Animals, Rembertów, Warsaw, Poland), which were divided into three control groups $\left(\mathrm{C}_{1}, \mathrm{C}_{2}, \mathrm{C}_{3}\right)$ and three experimental groups $\left(\mathrm{E}_{1}, \mathrm{E}_{2}, \mathrm{E}_{3}\right)$. All animals were in fixed environmental conditions with water and feed $[12,13]$ being freely available. Only standard edpelleted LSMâ feed was used. After a twoweek acclimatisation period, the virgin females with a body mass $(238 \pm 24)$ g mated overnight (between $20.00-08.00$ ) with males in a ratio of 5:2. The presence of spermatozoa or a clot containing a mixture of semen and exfoliated vaginal epithelial in the morning vaginal swab was proof of successful copulation. The fertilised females were randomly divided into three control groups and three experimental groups, each consisting of 8 rats. The day of fertilisation was considered to be the first day of gestation.

The study used caffeine (Caffeine anhydrous powder, Sigma-Aldrich Chemie $\mathrm{GmbH}$, Germany) with a purity exceeding $99 \%$, administered in a dose of $30 \mathrm{mg} /$ day which according to the data in the literature should interfere with the rat's prenatal development $[13,14]$. 


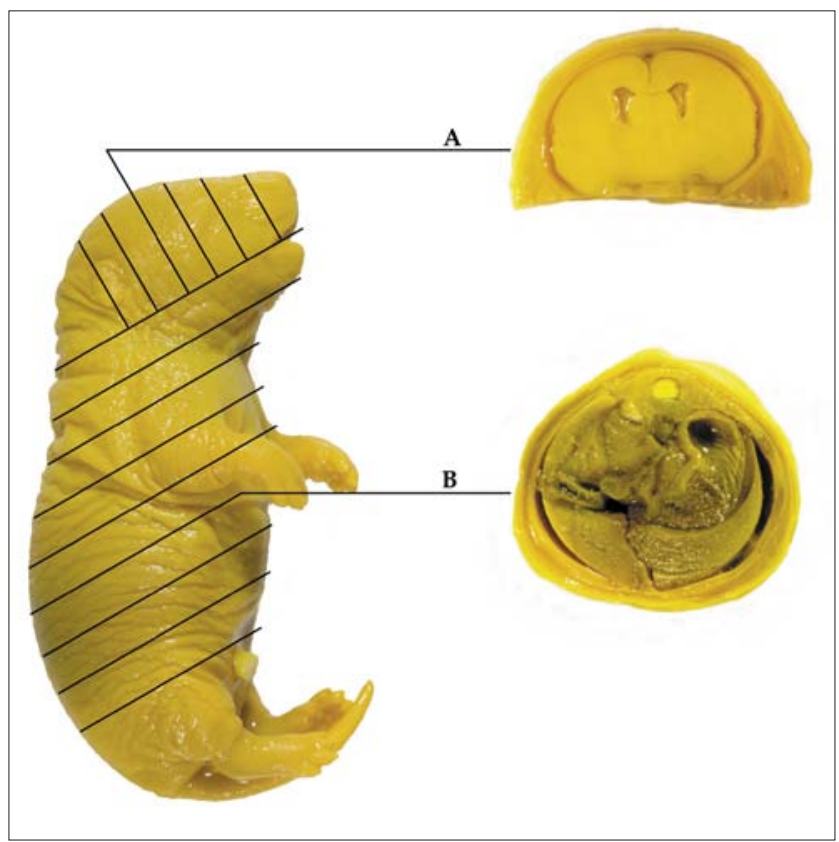

Figure 1. Cut lines and cross-sectional sample: front $(A)$ and transverse $(B)$ in 21-day foetal rat

The test substance was dissolved in sterile distilled water at three temperatures: $10^{\circ} \mathrm{C}, 25^{\circ} \mathrm{C}$ and $45^{\circ} \mathrm{C}$. A single daily dose of $2 \mathrm{ml} / \mathrm{kg}$ body mass was administered intragastrically to the females from day 8 to day 21 of gestation in Groups $\mathrm{E}_{1}, \mathrm{E}_{2}$ and $\mathrm{E}_{3}$. The females in the control groups $\left(\mathrm{C}_{1}, \mathrm{C}_{2}, \mathrm{C}_{3}\right)$ received the same amount of water at the same temperature as the those in their respective experimental groups $\left(\mathrm{E}_{1}, \mathrm{E}_{2}, \mathrm{E}_{3}\right)$.

On day 21 day of gestation, the pregnant females were killed by decapitation using a specially prepared laboratory guillotine. Death was caused by breaking the continuity of the spinal cord without damaging the continuity of the external layers. After cutting the covering tissues of the abdominal cavity, the uterus with the foetuses, the liver, kidney, spleen and heart were incised. The mothers' internal organs were weighed, while the offspring were examined using standard teratological methods $[2,15]$. The continuity of the coating and the formation of body parts such as: the head, ear turbinates, external nostrils, palate, tongue, eyelids, front and hind limbs, tail, external genitalia and anus were assessed.

The foetuses were put to sleep using liquid nitrogen vapour, fixed in Bouin solution for 14-16 days, and then dehydrated in $96 \%$ alcohol. The evaluation of the internal organs was performed using Wilson's method based on standard tertological (horizontal and coronal cross-sectional) cuts (Fig. 1). The extracted organs were assessed for shape, colour, and any developmental abnormalities [16].

Statistical Analysis. The Kormogolova-Smirnov test was used to check the distribution of the studied characteristics in the group. Depending on the distribution of values, the significance of the differences between the groups was evaluated using either the t-Student test or the U test (MannWhitney). The significance of the qualitative characteristics was tested using the $\chi^{2}$ test. For statistical analysis, the STATISTICA5.0 (Stat Soft Inc., USA) computer programme was used. Differences for which the significance coefficient was $\mathrm{p}<0.05$ were considered to be statistically significant.

\section{RESULTS}

In the studied population of rat foetuses, there were no significant external malformations in the individual groups. The continuity of the coating and the formation of body parts, such as: the head, ear turbinates, external nostrils, palate, tongue, eyelids, front and hind limbs, tail, external genitalia and anus were normal in all groups.

An examination of the internal organs revealed the presence of individual diaphragmatic hernias in foetuses from both the mothers receiving caffeine at $10^{\circ} \mathrm{C}$ as well as $45^{\circ} \mathrm{C}$ (Fig. 2, Tab. 1). Furthermore, developmental abnormalities were observed in the form of haematomas or saturated bleeding in the internal organs (Fig. 3, Tab. 1). Subcutaneous haemorrhages were located mostly in the interscapular region, and less frequently around the eyelids and nostril, and on the extensor surface of the paws.

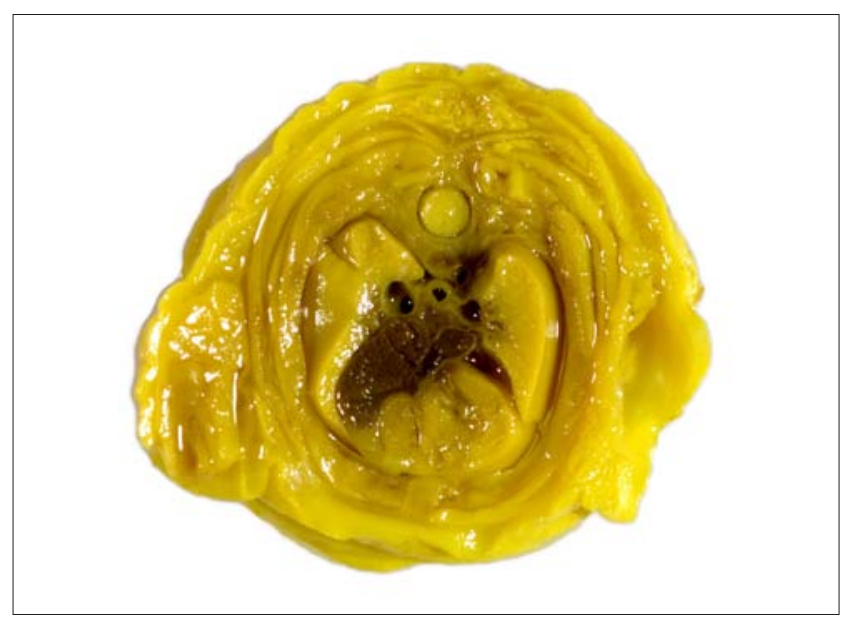

Figure 2. Incorrect position of liver in the mediastinum back - diaphragmatic hernia (group $\mathrm{E}_{3}$ )

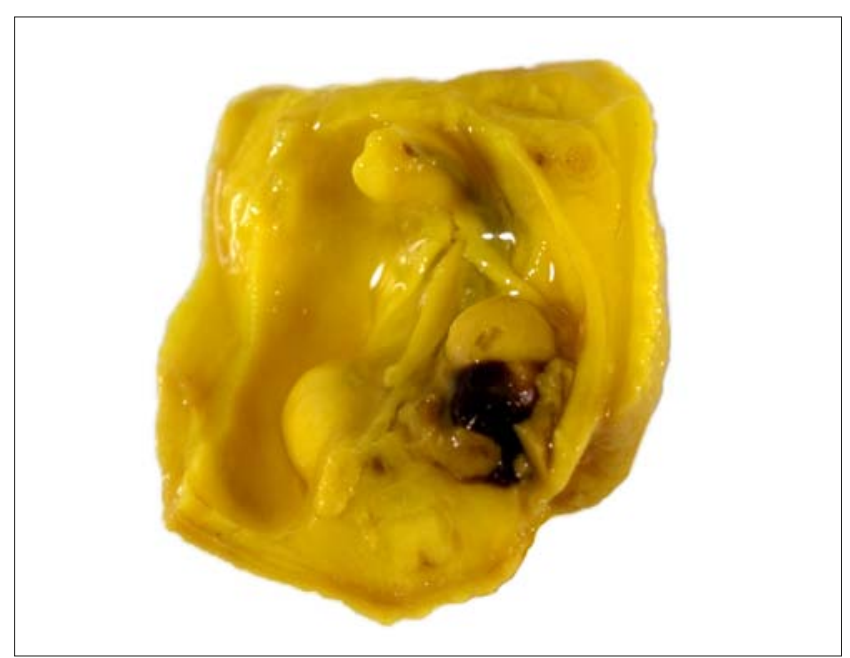

Figure 3. Haemorrhagic saturation of adrenal and retroperitoneal hematoma $\left(C_{1}\right)$

In the group of animals whose mothers received caffeine at $10^{\circ} \mathrm{C}$ or $45^{\circ} \mathrm{C}$ subcutaneous haematomas were observed significantly more frequently in the sublingual region, and saturation haemorrhaging in the lungs. Pericardial and retroperitoneal haematoma and saturation haemorrhaging of the adrenal glands occurred more frequently in all foetal groups whose mothers were given caffeine (Tab. 1). 
Table 1. The incidence of developmental defects and variations in the experimental groups $\left(E_{1}, E_{2}, E_{3}\right)$ and control $\left(C_{1}, C_{2^{\prime}} C_{3}\right)$

\begin{tabular}{|c|c|c|c|c|c|c|c|c|c|c|c|c|}
\hline & \multicolumn{2}{|c|}{$C_{1}$} & \multicolumn{2}{|c|}{$E_{1}$} & \multicolumn{2}{|c|}{$C_{2}$} & \multicolumn{2}{|c|}{$E_{2}$} & \multicolumn{2}{|c|}{$C_{3}$} & \multicolumn{2}{|c|}{$E_{3}$} \\
\hline & $\begin{array}{l}\text { number } \\
\text { of fetuses }\end{array}$ & $\begin{array}{l}\text { number } \\
\text { of litters }\end{array}$ & $\begin{array}{l}\text { number } \\
\text { of fetuses }\end{array}$ & $\begin{array}{l}\text { number } \\
\text { of litters }\end{array}$ & $\begin{array}{l}\text { number } \\
\text { of fetuses }\end{array}$ & $\begin{array}{l}\text { number } \\
\text { of litters }\end{array}$ & $\begin{array}{l}\text { number } \\
\text { of fetuses }\end{array}$ & $\begin{array}{l}\text { number } \\
\text { of litters }\end{array}$ & $\begin{array}{l}\text { number } \\
\text { of fetuses }\end{array}$ & $\begin{array}{l}\text { number } \\
\text { of litters }\end{array}$ & $\begin{array}{l}\text { number } \\
\text { of fetuses }\end{array}$ & $\begin{array}{l}\text { number } \\
\text { of litters }\end{array}$ \\
\hline number of live-born fetuses & 76 & 10 & 96 & 10 & 105 & 10 & 108 & 10 & 71 & 10 & 75 & 10 \\
\hline $\begin{array}{l}\text { fetuses examined by Wilson's } \\
\text { method }\end{array}$ & 38 & 10 & 48 & 10 & 53 & 10 & 54 & 10 & 36 & 10 & 38 & 10 \\
\hline the subcutaneous hematoma & 9 & 3 & $13^{*}$ & 5 & 6 & 3 & 11 & 5 & 8 & 3 & 12 & 5 \\
\hline the sublingual region hematoma & 2 & 1 & $11^{*}$ & 5 & - & - & 5 & 2 & - & - & 9 & 4 \\
\hline the pericardial haemoma & 3 & 2 & 5 & 3 & - & - & 3 & 3 & - & - & 4 & 2 \\
\hline the retroperitoneal hematoma & - & - & 5 & 5 & - & - & 3 & 2 & - & - & 4 & 3 \\
\hline $\begin{array}{l}\text { saturation hemorrhaging in the } \\
\text { adrenal glands }\end{array}$ & 1 & 1 & 9 & 5 & - & - & 2 & 1 & - & - & $11^{*}$ & 7 \\
\hline $\begin{array}{l}\text { saturation hemorrhaging in the } \\
\text { lungs }\end{array}$ & 2 & 1 & $13^{*}$ & 6 & - & - & 7 & 3 & - & - & 6 & 3 \\
\hline the diaphragmatic hernia & - & - & 1 & 1 & - & - & - & - & - & - & 3 & 2 \\
\hline
\end{tabular}

*significant statistically $(p<0.05)$

Table 2. Organ weight of pregnant female with a standard deviation $( \pm S D)$ and significance levels between the groups $(p<0.05)$

\begin{tabular}{|c|c|c|c|c|c|c|c|}
\hline \multirow{2}{*}{ organ weight [g] } & \multicolumn{6}{|c|}{ group of animals } & \multirow{2}{*}{$\begin{array}{l}\text { significance levels between } \\
\text { the groups }(p<0.05)\end{array}$} \\
\hline & $C_{1}$ & $\mathrm{E}_{1}$ & $\mathrm{C}_{2}$ & $\mathrm{E}_{2}$ & $\mathrm{C}_{3}$ & $\mathrm{E}_{3}$ & \\
\hline liver & $13.915 \pm 0.732$ & $12.998 \pm 2.111$ & $12.463 \pm 1.437$ & $15.060 \pm 2.252$ & $12.535 \pm 1.648$ & $14.523 \pm 3.373$ & $E_{1}$ vs $E_{2} ; E_{2}$ vs $C_{2} ; E_{2}$ vs $C_{3}$ \\
\hline right kidney & $1.016 \pm 0.086$ & $0.890 \pm 0.078$ & $0.839 \pm 0.104$ & $0.956 \pm 0.109$ & $0.850 \pm 0.099$ & $0.916 \pm 0.223$ & $E_{1}$ vs $C_{1} ; C_{1}$ vs $C_{2} ; C_{1}$ vs $C_{3}$ \\
\hline left kidney & $0.955 \pm 0.101$ & $0.851 \pm 0.091$ & $0.821 \pm 0.139$ & $0.926 \pm 0.099$ & $0.818 \pm 0.123$ & $0.893 \pm 0.153$ & $E_{1}$ vs $C_{1} ; C_{1}$ vs $C_{2} ; C_{1}$ vs $C_{3}$ \\
\hline spleen & $0.926 \pm 0.127$ & $0.609 \pm 0.108$ & $0.605 \pm 0.088$ & $0.624 \pm 0.171$ & $0.650 \pm 0.160$ & $0.563 \pm 0.204$ & $\begin{array}{c}\mathrm{E}_{1} \text { vs } \mathrm{C}_{1} ; \mathrm{C}_{1} \text { vs } \mathrm{E}_{2} ; \mathrm{C}_{1} \text { vs } \mathrm{C}_{2} ; \mathrm{C}_{1} \\
\text { vs } \mathrm{E}_{3} ; \mathrm{C}_{1} \text { vs } \mathrm{C}_{3}\end{array}$ \\
\hline heart & $1.138 \pm 0.110$ & $1.058 \pm 0.198$ & $1.183 \pm 0.145$ & $1.243 \pm 0.219$ & $1.115 \pm 0.304$ & $1.109 \pm 0.126$ & ns \\
\hline
\end{tabular}

ns - insignificant statistically $(p>0,05)$

Significant differences in the weight of internal organs were also found between the groups of females given caffeine and water. Significant differences in liver weight were observed between the groups receiving caffeine at $10^{\circ} \mathrm{C}$ and $25^{\circ} \mathrm{C}$, as well as between those given caffeine at room temperature and their respective control group (Tab. 2). The greatest liver weights were found in the group of females receiving caffeine at $25^{\circ} \mathrm{C}$, and the smallest in group $\mathrm{C}_{2}$.

Significant differences were noted between the groups given caffeine and water at $10^{\circ} \mathrm{C}$, and the control groups: $\mathrm{C}_{1}$ relative to $\mathrm{C}_{2}$ and $\mathrm{C}_{1}$ relative to $\mathrm{C}_{3}$ (Tab. 2) for the weights of the left and right kidney. These differences were similar. Also, significant differences were observed in the weight of the spleen between the groups receiving caffeine at $10^{\circ} \mathrm{C}, 25^{\circ} \mathrm{C}$ or $45^{\circ} \mathrm{C}$ and water at $10^{\circ} \mathrm{C}$ and between the control groups: $\mathrm{C}_{1}, \mathrm{C}_{2}$, and $\mathrm{C}_{3}$ (Table 2). However, there were no significant weight differences of the heart between the experimental and control groups.

\section{DISCUSSION}

Caffeine readily crosses the placental barrier and into the milk of nursing mothers [6], and numerous attempts have been made to assess the impact of caffeine on embryonic and foetal development. Many experimental studies on animals have shown teratogenic and embryotoxic effects of high caffeine doses. Nishimura and Nakai [17] were the first to discover that caffeine administered intraperitoneally to pregnant mice in a dose of $250 \mathrm{mg} / \mathrm{kg}$ caused abnormalities in the offspring. Cleft palate and defects in the digits were observed in $43 \%$ of offspring whose mothers received caffeine between day 10 and day 14 of gestation.

To the best of our knowledge, there are no reports in the literature on the influence of caffeine at various temperatures on the foetus development. In the presented study it was found that caffeine in the dose of $30 \mathrm{mg} /$ day in the temperatures $10^{\circ} \mathrm{C}$ and $45^{\circ} \mathrm{C}$, in individual cases caused diaphragmatic hernias in foetuses. Furthermore, developmental abnormalities were observed in the form of haematomas or saturated bleeding in the internal organs.

It is difficult to compare these results with the data in the literature because of differences in the experimental methodology. In most of the available articles, the authors administered a higher doses of caffeine.

Elmazar et al. [13] found that mouse foetuses, whose mothers received methylxanthine between day 6 and day $16^{\text {th }}$ of gestation in a dose of $150 \mathrm{mg} / \mathrm{kg}$ administered in drinking water had deformed feet and large subcutaneous haemorrhaging. After providing caffeine in feed in a dose of $50 \mathrm{mg} / \mathrm{kg}, 2$ foetuses out of 209 had a cleft palate (complete cleft), another 4 were born with deformed feet, subcutaneous haematomas, dilated renal pelvis and a cyst in the bronchus. After providing caffeine in feed in a dose of $150 \mathrm{mg} / \mathrm{kg}$ eight out of 137 foetuses had large malformations: anencephaly (5), cleft palate (2) and a cleft lip (1). Moreover, 4 foetuses had deformed feet (2), subcutaneous haematomas (1) and a dilated renal pelvis (1). 
Evereklioglu et al. [18] have shown the negative effect of high caffeine doses on foetal cornea. They administered caffeine intraperitoneally to female rats between day 9 and day 21 of gestation in doses of 25,50 and $100 \mathrm{mg} / \mathrm{kg}$, and a $50 \mathrm{mg} / \mathrm{kg}$ dose intragastrically. In the foetal group where mothers received higher caffeine doses there was a proliferation of endothelium cells with hyperchromasia, and an irregular arrangement of endothelium cells. There was also an increase in the mitotic activity of stromal cells and corneal oedema with visible irregular damaged stromal fibres. Additionally, in some suckling rats there was agenesis of the corneal endothelium cells.

Complementing these studies were the experiments of Kujawa-Hadryśet al. [6,7] on 26 chicken embryos. The researchers administered caffeine in a dose of $3.5 \mathrm{mg} /$ embryo. Their research did not show any differences in the construction of the cornea between the left and right eyeball, nor between the experimental and control groups, with the corneal layers remaining unchanged (corneal epithelium, anterior limiting membrane/Bowman's layer, corneal stroma, posterior limiting membrane/Descemet's membrane, corneal endothelium). The changes which they recorded concerned the quantitative composition (reduction in thickness) and qualitative (irregularity of the collagen fibres, a reduction in the number of cells) in both the corneal stroma as well as in the Bowman's layer.

Wilkinson and Pollard presented the results of their research [19] on the impact of caffeine on the development of a foetus's central nervous system. In foetuses whose mothers received $25 \mathrm{mg} / \mathrm{kg}$ doses of caffeine on day 8 and day 9 of gestation, in $55 \%$ of cases the closure of the neural folds in the cranial region did not occur, compared to $31 \%$ of the animals in the control group. However, non-closure in the caudal region occurred in $91 \%$ and $14 \%$ of foetuses, respectively. The foetuses of females exposed to caffeine also showed impaired intrauterine growth characteristics; however, the authors do not specify whether the changes they observed on day 10 day of gestation in the offspring, incurred consequences at the end of gestation and after birth, or whether they were averaged within the control group.

Fedrick [20] described 558 anencephalic foetal cases in a group of mothers who drank 3 cups of tea daily during pregnancy (more than $2.1 \mathrm{mg}$ of caffeine $/ \mathrm{kg}$ ). Borlee et al. [21] reported 190 cases of birth defects in children whose mothers drank eight cups of coffee daily during pregnancy (16 mg caffeine $/ \mathrm{kg}$ ). These results were confirmed by Furuhashi et al. [22]. Defects and developmental disorders occurred twice as frequently in the children of mothers who drank beverages high in caffeine. In the analysed group, heart defects, cleft palates, supernumerary fingers, and complex defects were observed with some cases being due to chromosome abnormalities. However, these observations have not been confirmed in other studies. Linn et al. [23] did not report an association between an increased risk of birth defects in children whose mothers consumed 4 cups of coffee daily during the first trimester of pregnancy. Also, Kurppa et al. [24] in a study on a group of 706 women, found no relationship between caffeine and the incidence of birth defects in the offspring. The incidence of abnormal development in the newborns of mothers who drank 6 cups of coffee daily, or who did not drink coffee, were comparable.

The literature also describes instances of the negative effects of caffeine ingested shortly before birth. Oei and
Vosters [25] described 2 infants with an irregular heartbeat, bradycardia, and additional supraventricular beats. Their mothers drank beverages with high caffeine content just before giving birth. The observed arrhythmia disappeared of its own accord during the second day of life.

\section{CONCLUSIONS}

On the basis of the undertaken experiments it was found that a $30 \mathrm{mg} /$ day caffeine dose administered at $10^{\circ} \mathrm{C}$ and $45^{\circ} \mathrm{C}$ caused individual cases of diaphragmatic hernias. Additionally, the sign of its adverse effect was the appearance of developmental abnormalities in the form of haematomas and saturated bleeding in the internal organs. These changes most frequently occurred in foetuses of females who received caffeine at $10^{\circ} \mathrm{C}$ or $45^{\circ} \mathrm{C}$.

\section{REFERENCES}

1. Nikolic J, Bjelakovic G, Stojanovic I. Effect of caffeine on metabolizm of L-arginine in the brain. Mol Cell Biochem. 2003; 244: 125-128.

2. Christian MS. Test methods for assessing female reproductive and developmental toxicology. In: Hayes AW. (ed): Principles and method of toxicology. Ed. 4. Taylor and Francis. Philadelphia. 2001: 1301-1381.

3. Christian MS, Brent RL. Teratogen update: Evaluation of the reproductive and developmental risks of caffeine. Teratology. 2001; 64: 51-78.

4. Nawrot P, Jordan S, Eastwood J, Hugenholtz A, Feeley M. Effects of caffeine on human health. Food Addit Contam. 2003; 20: 1-30.

5. Soellner DE, Grandys T, Nunez JL. Chronic prenatal caffeine exposure impairs novel object recognition and radial arm maze behaviors in adult rats. Behav Brain Res. 2009; 14, 205, 1, 191-199.

6. Kujawa-Hadryś M, Tosik D, Bartel H. Changes in thickness of each layer of developing chicken cornea after administration of caffeine. Folia Histochem Cytobiol. 2010a; 48(2): 273-277.

7. Kujawa-Hadryś M, Tosik D, Bartel H. Ultrastructural changes in the developing chicken cornea following caffeine administration. Folia Histochem Cytobiol. 2010b; 48(3): 371-376.

8. Olchowik G, Chadaj-Polberg E, Tomaszewski M, Polberg M, Tomaszewska M. The influence of caffeine on the biomechanical properties of bone tissue Turing pregnancy in a population of rats. Folia Histochem Cytobiol. 2011; 49(3): 504-511.

9. Tomaszewski M, Olchowik G, Tomaszewska M, Burdan F. Use of X-ray microprobe to diagnose bone tissue demineralization after caffeine administration. Folia Histochem Cytobiol. 2012; 50(3): 436-443.

10. EMEA 2000. Note for guidance on repated dose toxity. CMP/ SWP/1042/99. http://www.emea.eu.int/

11. WHO 2001. World Health Organization. Principles for evaluating health risks to reproduction associated with exposure to chemicals. Environ Health Criteria 225, 1-185.

12. ICH 2000. ICH Harmonised tripartite guideline. Maintenance of the ICH guideline on toxicity to male fertility. An addendum to ICH tripartite guideline on detection of toxicity to reproduction for medicinal products. http://www.ifpma.org/ich1.html.

13. Elmazar MMA, McElhatton PR, Sullivan FM. Studies on the teratogenic effects of different oral preparations of caffeine in mice. Toxicology. 1982; 23: 57-71.

14. Burdan F, Madej B, Wójtowicz Z, Maciejewski R, Radzikowska E. The effects of short - time caffeine administration on skeleton development in Wistar rats. Folia Morphol (Warsz). 2000; 59: 91-95.

15. Burdan F, Szumiło J, Dudka J, Klepacz R, Błaszczak M, Solecki M, Korobowicz A, Chłas A, Klepacki J, Palczak M, Zuchnik-Wrona A, Hadała-Kiś A, Urbanowicz Z, Wojtowicz Z. Morphological studies in modern teratological investigations. Folia Morphol (Warsz). 2005; 64: 1-8.

16. DevTox 2007 http//www.devtox.org.

17. Nishimura H, Nakai K. Congenital malformations in offspring of mice treated with caffeine. Proc Soc Exp Med. 1960; 104: 140-142.

18. Evereklioglu C, Sari I, Alasehirli B, Guldur E, Cengiz B, Balat Z, Bagci C. High dose of caffeine administered to pregnant rats causes 
histopathological changes in the cornea of newborn pups. Med Sci Monit. 2003; 9: 168-173.

19. Wilkinson J, Pollard I. In utero exposure to caffeine causes delayed neural tube closure in rat embryos. Teratog Carcinog Mutagen. 1994; 14: 205-211.

20. Fedrick B. Anencephalus and maternal tea drinking: evidence for a possible association. Proc R Soc Med. 1974; 67: 356-360.

21. Borlee I, Lechat MF, Bouckaert A, Misson C. Le cafè, facteur de risqué pedant la grossesse? Louvain Med. 1978; 97: 279-284.
22. Furuhashi N, Sato S, Suzuki M, Hiruta M, Tanaka M, Takahashi T. Effect of caffeine ingestion during pregnancy. Gynecol Obstet Invest. 1985; 19: 187-191.

23. Linn S, Schoenbaum SC, Monson RR, Rosner B, Stubblefield PG, Ran KJ. No association between coffee consumption and adverse outcomes of pregnancy. N Engl J Med. 1982; 306: 141-145.

24. Kurppa K, Holmberg PC, Kuosma E, Saxen L. Coffee consumption during pregnancy and selected congenital malformtions: a nationwide case - control study. Am J Public Health. 1983; 73: 1397-1399.

25. Oei SG, Vosters RPL. Fetal arrhythmia caused by excessive intake caffeine by pregnant women. BMJ. 1989; 28: 568. 